\title{
Acute stress negatively affects object recognition early memory consolidation and memory retrieval unrelated to state-dependency
}

Citation for published version (APA):

Nelissen, E., Prickaerts, J., \& Blokland, A. (2018). Acute stress negatively affects object recognition early memory consolidation and memory retrieval unrelated to state-dependency. Behavioural Brain Research, 345, 9-12. https://doi.org/10.1016/j.bbr.2018.02.027

Document status and date:

Published: 01/06/2018

DOI:

10.1016/j.bbr.2018.02.027

Document Version:

Publisher's PDF, also known as Version of record

Document license:

Taverne

Please check the document version of this publication:

- A submitted manuscript is the version of the article upon submission and before peer-review. There can be important differences between the submitted version and the official published version of record.

People interested in the research are advised to contact the author for the final version of the publication, or visit the DOI to the publisher's website.

- The final author version and the galley proof are versions of the publication after peer review.

- The final published version features the final layout of the paper including the volume, issue and page numbers.

Link to publication

\footnotetext{
General rights rights.

- You may freely distribute the URL identifying the publication in the public portal. please follow below link for the End User Agreement:

www.umlib.nl/taverne-license

Take down policy

If you believe that this document breaches copyright please contact us at:

repository@maastrichtuniversity.nl

providing details and we will investigate your claim.
}

Copyright and moral rights for the publications made accessible in the public portal are retained by the authors and/or other copyright owners and it is a condition of accessing publications that users recognise and abide by the legal requirements associated with these

- Users may download and print one copy of any publication from the public portal for the purpose of private study or research.

- You may not further distribute the material or use it for any profit-making activity or commercial gain

If the publication is distributed under the terms of Article $25 \mathrm{fa}$ of the Dutch Copyright Act, indicated by the "Taverne" license above, 
Short communication

\title{
Acute stress negatively affects object recognition early memory consolidation and memory retrieval unrelated to state-dependency
}

\author{
Ellis Nelissen ${ }^{\mathrm{a}}$, Jos Prickaerts ${ }^{\mathrm{a}}$, Arjan Blokland ${ }^{\mathrm{b}, *}$ \\ a Department of Psychiatry and Neuropsychology, School for Mental Health and Neuroscience, Maastricht University, PO Box 616, 6200 MD, Maastricht, The Netherlands \\ b Department of Neuropsychology and Psychopharmacology, Maastricht University, PO Box 616, 6200 MD, Maastricht, The Netherlands
}

\section{A R T I C L E I N F O}

\section{Keywords:}

Stress

Memory

Acquisition

Consolidation

Retrieval

State-dependency

\begin{abstract}
A B S T R A C T
It is well known that stress affects memory performance. However, there still appears to be inconstancy in literature about how acute stress affects the different stages of memory: acquisition, consolidation and retrieval. In this study, we exposed rats to acute stress and measured the effect on memory performance in the object recognition task as a measure for episodic memory. Stress was induced $30 \mathrm{~min}$ prior to the learning phase to affect acquisition, directly after the learning phase to affect consolidation, or $30 \mathrm{~min}$ before the retrieval phase to affect retrieval. Additionally, we induced stress both $30 \mathrm{~min}$ prior to the learning phase and 30 min prior to the retrieval phase to test whether the effects were related to state-dependency. As expected, we found that acute stress did not affect acquisition but had a negative impact on retrieval. To our knowledge, we are the first to show that early consolidation was negatively affected by acute stress. We also show that stress does not have a state-dependent effect on memory.
\end{abstract}

Acute stress exposure results in the activation of the sympathetic nervous system and the hypothalamic-pituitary-adrenal (HPA) axis, leading to the release of catecholamines and glucocorticoids respectively [1-3]. After release, glucocorticoids (GCs), cortisol in humans and corticosterone in rodents, can bind to two types of GC receptors, which are differentially distributed in the central nervous system. The mineralocorticoid receptor (MR) has a high affinity for GCs and is mostly located to limbic regions, whereas the glucocorticoid receptor (GR) has a low affinity for GCs and is mostly located to sub-cortical and cortical regions. Both of the receptor types are highly expressed in the hippocampus [4]. Obviously, the effects of GC release on the central nervous system are dependent on the level of the GCs and the proportion of MRs and GRs saturated.

Acute activation of the MR facilitates acquisition and extinction processes, whereas the GR is essential for consolidation and detrimental for retrieval of declarative/episodic memory [5]. Additionally, studies have shown involvement of players other than GCs in different memory processes, including vasopressin and its vasopressin $1 \mathrm{~b}$ receptor [6], cannabinoid receptors [7], and the endogenous opioid system [8]. The understanding of the effect of acute stress on the different memory processes, i.e. acquisition, consolidation and retrieval, has grown over the recent years $[9,10]$. However, there is still a lot of inconsistency in literature, which has a lot to do with the differential effects that acute stress can have. In fact, a lot the effects of acute stress on different memory processes depends on the type of stress, the intensity of the stress, and the context of the stressor $[9,11]$. Furthermore, it is unknown whether the effects of acute stress on memory are the result of a state-dependent effect, which has been shown for other treatment conditions (e.g. [12]).

A study by Li et al. already elaborated on the effect of acute restraint stress on the different stages of memory [13]. However, it remains unclear whether there is an effect on early consolidation, and whether the effects found can be related to state-dependency. In order to further explore the effects of acute stress on episodic memory, and whether these effects are related to state-dependency, we used the object recognition task (ORT) in rats with acute stress induced at different time points to affect either acquisition, consolidation or retrieval. A statedependent effect was assessed by inducing stress before the first as well as before the second trial. Furthermore, we established a forgetting curve to determine the optimal inter-trial interval for measuring the effects of acute stress on the different stages of memory, and in particular early consolidation.

The object recognition task was performed as described previously $[14,15]$. In brief, in a first learning trial (T1), the rat is allowed to explore a circular arena with two identical objects for $3 \mathrm{~min}$. After an interval of $3 \mathrm{~h}$, the rat is placed back into the arena, with one of the objects replaced by a novel object (T2), and is again allowed to explore for $3 \mathrm{~min}$. Exploration time for each object is recorded, and the main

\footnotetext{
* Corresponding author.

E-mail address: a.blokland@maastrichtuniversity.nl (A. Blokland).
} 
outcome measure is the discrimination index (d2), which is the difference in exploration time between the novel and familiar object, divided by the total exploration time. All animals were first habituated to handling, the arena, and the objects, and all animals were trained until a stable forgetting curve could be obtained ranging from $1 \mathrm{~h}$ to $24 \mathrm{~h}$ intervals (see [16] for full details). We applied a $3 \mathrm{~h}$ inter-trial interval based on the forgetting curve, since this was the longest interval where a reliable memory performance could be observed in order to assess possible negative impact of stress. Approximately $100 \mu \mathrm{l}$ of blood was taken to measure corticosterone levels at baseline, $30 \mathrm{~min}$ after acute stress exposure, and $45 \mathrm{~min}$ after stress exposure. Blood samples were collected via saphenous vein puncture using a heparin-coated tubes and were kept on ice and subsequently centrifuged at $5000 \mathrm{rpm}$ for $10 \mathrm{~min}$ at $4{ }^{\circ} \mathrm{C}$, after which the plasma was frozen down to $80^{\circ} \mathrm{C}$ for subsequent determination. All samples were run in duplicate using a commercially available RIA kit for rat corticosterone from MP Biomedicals (Corticosterone $\mathrm{I}^{125}$ for rodents, MP Biomedicals). The stress conditions were compared with a virtual group that shows no discrimination $(\mathrm{d} 2=0)$ and a standard error mean (SEM) that corresponds to the average SEM (0.065) of independent samples in previous studies [17], in order to determine whether the stress impaired memory. A one-way ANOVA with a Dunnett post-hoc test was used to compare the conditions with the virtual group. Comparisons between corticosterone time points were done using a one-way repeated measures ANOVA with a Dunnett post-hoc test. Comparisons between exploration times were done using a one-way ANOVA with Bonferroni post-hoc test.

The study was approved by the local Animal Ethical Committee according to governmental guidelines. Acute stress was induced in twenty-four three-month-old male Wistar rats (310-390 grams) by placing the animals in a standard type 3 Makrolon cage filled with $2 \mathrm{~cm}$ of water $\left(20^{\circ} \mathrm{C}\right)$ for $5 \mathrm{~min}$. To affect acquisition processes, we administered the stress $30 \mathrm{~min}$ before T1. Stress was administered immediately after $\mathrm{T} 1$ to affect the consolidation processes. To affect retrieval processes we administered the stress $30 \mathrm{~min}$ before T2. Finally, we examined the state-dependency of these effects by administering the stress $30 \mathrm{~min}$ before $\mathrm{T} 1$ and before $\mathrm{T} 2$. For unstressed conditions, again twenty-four three-month-old male Wistar rats weighing 310-390 grams were used. The animals were housed individually in standard type 3 Makrolon cages with sawdust bedding in an air-conditioned room, with a reversed light/dark cycle of 12/12 h (lights off from 5:00 to 17:00). Exploration times were scored manually by an experimenter who was blinded to the experimental conditions.

A forgetting curve was established, which showed that the length of the inter-trial interval had a significant effect on memory ( $F$ $(4,115)=4.629 ; \mathrm{P}<0.01)$. Animals were able to remember the familiar object after a $1 \mathrm{~h}(\mathrm{P}<0.001)$ and $3 \mathrm{~h}(\mathrm{P}<0.001)$ inter-trial interval, but not after $5 \mathrm{~h}$ or $24 \mathrm{~h}$ (Fig. $1 \mathrm{~A}$ ). This indicates that the animals were properly habituated to the arena and the objects, and the 3-h inter-trial interval was the maximal interval to examine possible detrimental effects of stress in the different stages of memory. Corticosterone levels were increased three-fold $(\mathrm{F}(1.609,16.09)=18.22$; $\mathrm{P}<0.001)$ compared to baseline at $30 \mathrm{~min}(\mathrm{P}<0.001)$ and $45 \mathrm{~min}$
( $\mathrm{P}<0.001$ ) following acute stress exposure (Fig. 1B), suggesting that the stress induction was successful. Total exploration times for T1 (e1) and $\mathrm{T} 2$ (e2) were significantly different (e1 $\mathrm{F}(4,115)=21.61$; $\mathrm{P}<0.001$; e2 $\mathrm{F}(4,115)=40.38 ; \mathrm{P}<0.001)$. For the unstressed condition, e1 $=27.9 \pm 2.5 \mathrm{~s}$ ( $\mathrm{P}<0.05$ compared to all stressed conditions) and $\mathrm{e} 2=24.9 \pm 1.6(\mathrm{P}<0.05$ compared to all stressed conditions). When exposed to acute stress $30 \mathrm{~min}$ before $\mathrm{T} 1$, $\mathrm{e} 1=11.0 \pm 1.0$ and $\mathrm{e} 2=10.8 \pm 1.1$; when exposed to acute stress directly after $\mathrm{T} 1, \mathrm{e} 1=11.9 \pm 1.0$ and $\mathrm{e} 2=11.3 \pm 0.9$; for acute stress $30 \mathrm{~min}$ before $\mathrm{T} 2$, e $1=12.1 \pm 1.1$ and $\mathrm{e} 2=12.9 \pm 1.0$; and when exposed to stress $30 \mathrm{~min}$ before $\mathrm{T} 1$ and before $\mathrm{T} 2$, $\mathrm{e} 1=39.4 \pm 5.3$ ( $\mathrm{P}<0.001$ compared to the other stress conditions $)$ and $\mathrm{e} 2=31.6 \pm 2.3(\mathrm{P}<0.001$ compared to the other stress conditions). Under unstressed conditions, animals were able to remember the familiar object $(P<0.001)$, and similar results were found when animals were exposed to acute stress $30 \mathrm{~min}$ before $\mathrm{T} 1$ ( $\mathrm{P}<0.05$ ), suggesting that acquisition processes were not affected upon acute stress (Fig. 2A). A one-way ANOVA showed that stress had a negative effect on memory $(\mathrm{F}(4,115)=4.494 ; \mathrm{P}<0.01)$. When animals were stressed immediately after $\mathrm{T} 1$, or $30 \mathrm{~min}$ before $\mathrm{T} 2$, animals were unable to remember the familiar object $(\mathrm{P}=0.233$ and $\mathrm{P}=0.834$ respectively, compared to the virtual group), suggesting that both memory consolidation and retrieval were negatively affected by acute stress exposure (Fig. 2A). The effects of acute stress were not caused by a statedependent effect, since stress $30 \mathrm{~min}$ before both $\mathrm{T} 1$ and $\mathrm{T} 2$ also resulted in animals forgetting the familiar object (Fig. 2B; $\mathrm{P}=0.696$ compared to the virtual group).

The current study showed that 5-min, acute stress exposure increased corticosterone levels three-fold, and negatively affected memory consolidation and retrieval. No effects were found for acquisition, which is consistent with previous literature [13]. The effects of acute stress on retrieval are consistent with many other studies (for an in-depth review, see [18]; for a meta-analysis, see [9]), and the first study already dates back to 1998, when de Quervain and colleagues found that stress prior to long-term memory retrieval negatively affected spatial memory [19]. Based on our forgetting curve, we used a 3$\mathrm{h}$ inter-trial interval to measure the effects of stress on acquisition, consolidation, and retrieval. Early consolidation is known to last until $3 \mathrm{~h}$ after the learning phase, whereas late consolidation only starts after $3 \mathrm{~h}$. Given the length of our inter-trial interval, we are most likely measuring the effects of acute stress on early consolidation. Therefore, the results indicate that acute stress negatively affects early consolidation, and to our knowledge we are the first to show this. Additionally, given the length of the inter-trial interval, it cannot be excluded that the effects found on retrieval when animals were exposed to acute stress $30 \mathrm{~min}$ before $\mathrm{T} 2$ may also be the result of an interference with the late phase of early consolidation.

Total exploration times for $\mathrm{T} 1$ and $\mathrm{T} 2$ were significantly higher for the group receiving stress before $\mathrm{T} 1$ and $\mathrm{T} 2$ compared to unstressed conditions, whereas e1 and e2 were lower for all other groups compared to the unstressed group. A difference in exploration times is unexpected and may be the result of environmental factors. However, a
A

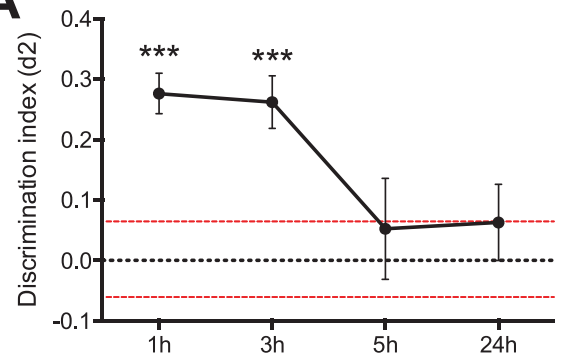

$\mathrm{P}<0.001 ; \mathrm{n}=12$. All data are represented as mean \pm SEM

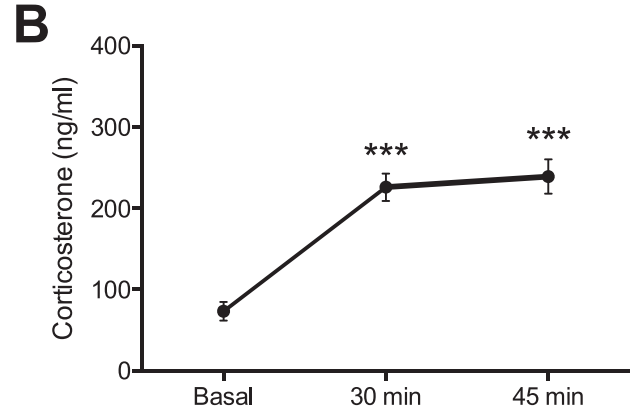

Basal
Fig. 1. (A) Forgetting curve depicting memory performance of the animals in the object recognition task (ORT) after several inter-trial intervals under unstressed conditions. Area between red dashed lines indicates the SEM range of the virtual group showing no discrimination (mean: 0, SEM: 0.065). Asterisks represent statistical significance from the virtual group (one-way ANOVA using a Dunnett's post-hoc test). ${ }^{* * *} \mathrm{P}<0.001, \mathrm{n}=24$. (B) The effects of acute stress on corticosterone levels measured $30 \mathrm{~min}$ and $45 \mathrm{~min}$ after stress exposure. Asterisks represent statistical significance (one-way repeated measures ANOVA, Dunnett's correction for multiple comparisons) compared to basal corticosterone levels. *** 
A

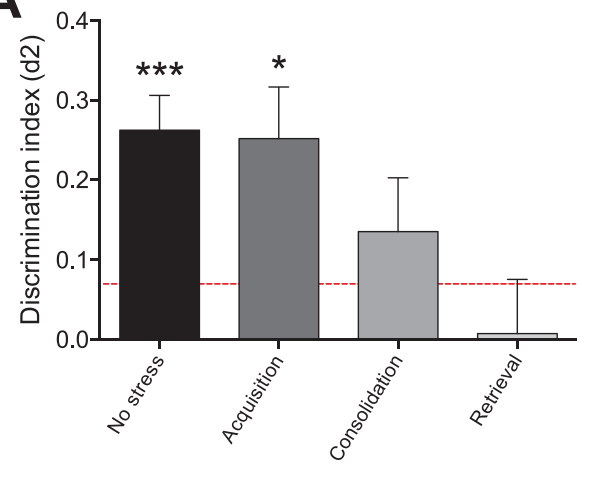

B

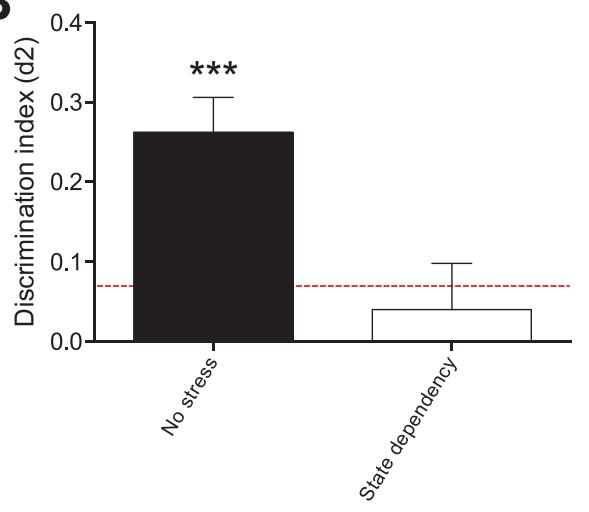

Fig. 2. (A) Memory performance of the animals in the object recognition task (ORT) using a $3 \mathrm{~h}$ delay between $\mathrm{T} 1$ and $\mathrm{T} 2$, measuring the effects of acute stress on acquisition ( $30 \mathrm{~min}$ before $\mathrm{T} 1$ ), consolidation (after T1) and retrieval (30 min before T2). (B) Memory performance of the animals after the removal of a possible state-dependent effect on retrieval (stress was applied $30 \mathrm{~min}$ before $\mathrm{T} 1$ and $30 \mathrm{~min}$ before T2). Area under the red dashed line indicates the SEM range of the virtual group showing no discrimination (mean: 0, SEM: 0.065). A difference from the virtual group is represented by asterisks (one-way ANOVA, Dunnett's correction for multiple comparisons). ${ }^{*} \mathrm{P}<0.05$, $* * \mathrm{P}<0.001$; $\mathrm{n}=24$. Data is represented as mean \pm SEM. correlation between exploration times and memory performance, and exploration times and stress, was not observed (see [16]). Furthermore, the exploration times are sufficient to calculate a reliable d2 [16].

Our study is similar to a recent study of Li et al. who measured the effects of acute restraint stress on memory acquisition, consolidation and retrieval in an ORT and an object location task [13]. Our findings on memory retrieval are consistent with their results, however, they were unable to find a significant effect on memory consolidation after an inter-trial interval of $4 \mathrm{~h}$. In contrast, they did find an impairing effect on memory consolidation after $24 \mathrm{~h}$. There are some differences between the current study and the study of Li et al. Most importantly, after extensive habituation to both the arena and the objects, we were able to establish a stable forgetting curve, which indicated that animals were unable to remember the familiar object after $5 \mathrm{~h}$ and $24 \mathrm{~h}$. However, in the study of Li et al., animals showed a good memory performance both after $4 \mathrm{~h}$ and $24 \mathrm{~h}$. Although the study did not provide all details of the test protocol, our previous studies would suggest that the animals were not habituated to the novelty of the objects (see [16]). Thus, the animals were still able to discriminate between the familiar and the novel object after $24 \mathrm{~h}$ because the objects still had a novelty aspect. In our study, the memory performance is more dependent on episodic memory since the animals had to discriminate on basis of when they explored which object. This procedural difference may explain the different outcomes of both studies on the stress effects on object memory. It would also imply that stress has a differential effect on novelty-based memory and episodic memory.

Besides an effect on early consolidation, it might be likely that encoding processes were affected as these processes are also active during a short period after acquisition. Encoding refers to the formation of relations between events in episodic memory, based on for instance categorical (object) information [20]. It also entails novelty/familiarity evaluation [21] and involves processes that operate beyond perceptual processes [22]. Hence, encoding can continue when the actual stimulus is no longer present [23]. Therefore, it could be that acute stress immediately after the learning phase affected memory (also) via an effect on encoding.

State-dependency was first discovered in 1937, and describes a phenomenon in which memory retrieval is most efficient when the subject is in the same state of consciousness during retrieval as they were during learning [24]. We already showed previously that memory performance in the ORT can be affected by a state-dependent effect [25]. This raises the question whether acute stress $30 \mathrm{~min}$ before $\mathrm{T} 1$ and $30 \mathrm{~min}$ before retrieval would improve memory due to a state-dependent effect, compared to stress $30 \mathrm{~min}$ before retrieval alone, where memory is clearly impaired. Of note, stress $30 \mathrm{~min}$ before $\mathrm{T} 1 \mathrm{did}$ not alter memory performance. Interestingly, memory performance was impaired both in the $30 \mathrm{~min}$ before $\mathrm{T} 2$ condition, and in the $30 \mathrm{~min}$ before $\mathrm{T} 1$ and $\mathrm{T} 2$ condition, suggesting that state-dependent memory may not be applicable in the case of stress.
The current study has demonstrated that acute stress impairs early consolidation and retrieval, whereas acquisition remains unaffected. Additionally, the effects found on memory retrieval were not the result of a state-dependent effect. To our knowledge, we are the first to show that the impairing effect of acute stress on memory retrieval in the ORT is not related to state-dependency. In addition, we show for the first time that early consolidation processes are affected by acute stress.

\section{References}

[1] M. Joels, T.Z. Baram, The neuro-symphony of stress, Nat. Rev. Neurosci. 10 (6) (2009) 459-466.

[2] Y.M. Ulrich-Lai, J.P. Herman, Neural regulation of endocrine and autonomic stress responses, Nat. Rev. Neurosci. 10 (6) (2009) 397-409.

[3] J.P. Herman, J.M. McKlveen, M.B. Solomon, E. Carvalho-Netto, B. Myers, Neural regulation of the stress response: glucocorticoid feedback mechanisms, Braz. J. Med. Biol. Res. 45 (4) (2012) 292-298.

[4] S.J. Lupien, F. Maheu, M. Tu, A. Fiocco, T.E. Schramek, The effects of stress and stress hormones on human cognition: implications for the field of brain and cognition, Brain Cogn. 65 (3) (2007) 209-237.

[5] J. Prickaerts, T. Steckler, Effects of glucocorticoids on emotion and memory processes in animals, in: T. Steckler, N. Kalin, J. Reul (Eds.), Handbook of Stress and the Brain, Part 1: the Neurobiology of Stress, Elsevier, Amsterdam, 2005, pp. 359-386.

[6] A. Barsegyan, P. Atsak, W.B. Hornberger, P.B. Jacobson, M.M. van Gaalen, B. Roozendaal, The vasopressin 1 b receptor antagonist A-988315 blocks stress effects on the retrieval of object-recognition memory, Neuropsychopharmacology 40 (8) (2015) 1979-1989.

[7] A. Busquets-Garcia, M. Gomis-Gonzalez, R.K. Srivastava, L. Cutando, A. OrtegaAlvaro, S. Ruehle, F. Remmers, L. Bindila, L. Bellocchio, G. Marsicano, B. Lutz, R. Maldonado, A. Ozaita, Peripheral and central CB1 cannabinoid receptors control stress-induced impairment of memory consolidation, Proc. Natl. Acad. Sci. U. S. A. 113 (35) (2016) 9904-9909.

[8] M.O. Nava-Mesa, M.R. Lamprea, A. Munera, Divergent short- and long-term effects of acute stress in object recognition memory are mediated by endogenous opioid system activation, Neurobiol. Learn. Mem. 106 (2013) 185-192.

[9] G.S. Shields, M.A. Sazma, A.M. McCullough, A.P. Yonelinas, The effects of acute stress on episodic memory: a meta-analysis and integrative review, Psychol. Bull. 143 (6) (2017) 636-675.

[10] O.T. Wolf, Stress and memory retrieval: mechanisms and consequences, Curr. Opin. Behav. Sci. 14 (Suppl. C) (2017) 40-46.

[11] E.R. de Kloet, M.S. Oitzl, M. Joels, Stress and cognition: are corticosteroids good or bad guys? Trends Neurosci. 22 (10) (1999) 422-426.

[12] R.C. Petersen, Retrieval failures in alcohol state-dependent learning, Psychopharmacology (Berl.) 55 (2) (1977) 141-146.

[13] S. Li, Y.X. Fan, W. Wang, Y.Y. Tang, Effects of acute restraint stress on different components of memory as assessed by object-recognition and object-location tasks in mice, Behav. Brain Res. 227 (1) (2012) 199-207.

[14] J. Prickaerts, H.W. Steinbusch, J.F. Smits, J. de Vente, Possible role of nitric oxidecyclic GMP pathway in object recognition memory: effects of 7-nitroindazole and zaprinast, Eur J. Pharmacol. 337 (2-3) (1997) 125-136.

[15] E. Bollen, D. Puzzo, K. Rutten, L. Privitera, J. De Vry, T. Vanmierlo, G. Kenis, A. Palmeri, R. D'Hooge, D. Balschun, H.M. Steinbusch, A. Blokland, J. Prickaerts, Improved long-term memory via enhancing cGMP-PKG signaling requires cAMPPKA signaling, Neuropsychopharmacology 39 (11) (2014) 2497-2505.

[16] S. Akkerman, A. Blokland, O. Reneerkens, N.P. van Goethem, E. Bollen, H.J. Gijselaers, C.K. Lieben, H.W. Steinbusch, J. Prickaerts, Object recognition testing: methodological considerations on exploration and discrimination measures, Behav. Brain Res. 232 (2) (2012) 335-347.

[17] S. Akkerman, J. Prickaerts, H.W. Steinbusch, A. Blokland, Object recognition testing: statistical considerations, Behav. Brain Res. 232 (2) (2012) 317-322..

[18] S.A. Gagnon, A.D. Wagner, Acute stress and episodic memory retrieval: 
neurobiological mechanisms and behavioral consequences, Ann. N. Y. Acad. Sci. 1369 (1) (2016) 55-75.

[19] D.J. de Quervain, B. Roozendaal, J.L. McGaugh, Stress and glucocorticoids impair retrieval of long-term spatial memory, Nature 394 (6695) (1998) 787-790.

[20] M. Lepage, R. Habib, H. Cormier, S. Houle, A.R. McIntosh, Neural correlates of semantic associative encoding in episodic memory, Brain Res. Cogn. Brain Res. 9 (3) (2000) 271-280

[21] R. Habib, A.R. McIntosh, M.A. Wheeler, E. Tulving, Memory encoding and hippocampally-based novelty/familiarity discrimination networks, Neuropsychologia 41 (3) (2003) 271-279.
[22] M. Lepage, A.R. McIntosh, E. Tulving, Transperceptual encoding and retrieval processes in memory: a PET study of visual and haptic objects, Neuroimage 14 (3) (2001) 572-584.

[23] S. Akkerman, A. Blokland, N.P. van Goethem, P. Cremers, C.L. Shaffer, S.M. Osgood, H.W. Steinbusch, J. Prickaerts, PDE5 inhibition improves acquisition processes after learning via a central mechanism, Neuropharmacology 97 (2015) 233-239.

[24] E. Girden, C. Ea, Conditioned Responses Curarized Striate Muscle Dogs, (1937).

[25] A. Blokland, J. Prickaerts, W. Honig, J. de Vente, State-dependent impairment in object recognition after hippocampal NOS inhibition, Neuroreport 9 (18) (1998) 4205-4208. 